EUROPEAN CENTRAL BANK

WORKING PAPER SERIES

NO. 368 I JUNE 2004

\title{
CAPITAL QUALITY IMPROVEMENT AND THE SOURCES OF GROWTH IN THE EURO AREA
}

by Plutarchos Sakellaris and Focco W. Vijselaar

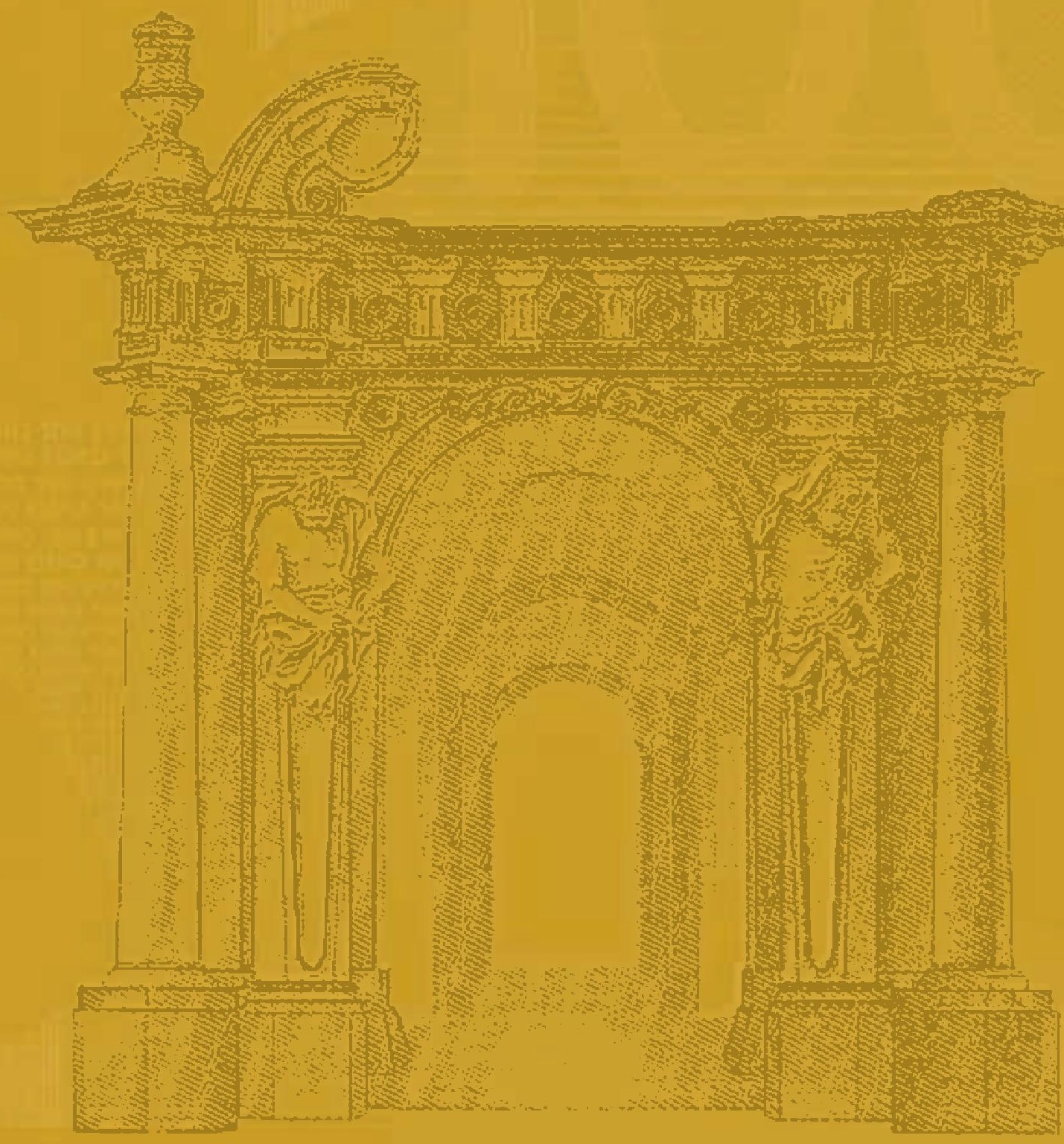




\author{
CAPITAL QUALITY \\ IMPROVEMENT AND \\ THE SOURCES OF \\ GROWTH IN THE \\ EURO AREA ${ }^{\prime}$
}

by Plutarchos Sakellaris ${ }^{2}$ and Focco W. Vijselaar ${ }^{3}$



This paper can be downloaded without charge from http://www.ecb.int or from the Social Science Research Network electronic library at http://ssrn.com/abstract_id $=533128$.

I We thank participants at a European Central Bank internal seminar, Ana Aizcorbe and participants at the ECB-CEPR-Banco de España Conference "Prices, Productivity and Growth" of October 2003 for useful comments. We thank Jason Cummins and Eric Bartelsman for providing us with data. Sakellaris thanks the staff of the Directorate General Research at the European Central Bank for their hospitality while writing this paper.The usual disclaimer applies. 2 University of Maryland, Athens University of Economics and Business, and IMOP, correspondence Department of Economics, AUEB, Patission 76, 10434 Athens, Greece. E-mail: plutarch@electra.umd.edu. 3 At the time of writing the author was affiliated with the European Central Bank. 


\section{드 European Central Bank, 2004}

\section{Address}

Kaiserstrasse 29

60311 Frankfurt am Main, Germany

Postal address

Postfach 160319

60066 Frankfurt am Main, Germany

Telephone

+496913440

\section{Internet}

http://www.ecb.int

Fax

+496913446000

Telex

411144 ecb d

All rights reserved.

Reproduction for educational and noncommercial purposes is permitted provided that the source is acknowledged.

The views expressed in this paper do not necessarily reflect those of the European Central Bank.

The statement of purpose for the ECB Working Paper Series is available from the ECB website, http://www.ecb.int.

ISSN 1561-0810 (print)

ISSN 1725-2806 (online) 


\section{CONTENTS}

Abstract

Non-technical summary

1. Introduction 7

2. A useful framework ?

2.1. The two production technologies 10

2.2. Estimating embodied technological change

3. Lessons for measurement

3.1. Productive capital stocks

3.2. Real output growth

3.3. growth accounting 19

4. Empirical results

4.1. Quality-adjusted price index for investment

4.2. Quality-adjusted E\&S capital stock and output

4.4. Contribution of quality-adjusted capital to economic growth

5. Conclusion

6. References

Annex

Tables

Appendix

European Central Bank working paper series 


\begin{abstract}
:
Capital quality improvement is a general phenomenon. Therefore quality correction is needed in price indexes. There is substantial evidence of biases in the official price indexes of capital equipment. We apply to euro area statistics estimates of these biases based on US data thus deriving quality-adjusted price indexes. Adjusted for quality, productive capital stocks of equipment and software grow on average 3 percentage points faster annually - a doubling of their growth rates. Quality-adjusted output grows 0.46 percentage points faster annually - a 20 percent increase. In terms of growth accounting, quality adjustment subtracts 11 percentage points from the share of TFP in aggregate growth and adds them to the share of equipment stock. For the 1990s only the difference is even higher: 14 percentage points. When all is told, embodied technological change accounts for 46 percent of (quality-adjusted) output growth in the euro area over the period 1982 to 2000.
\end{abstract}

Key words: output growth, embodied technological change, equipment investment, investment price deflators, euro area.

JEL codes: O3, O47, D24, E22 


\section{Non-technical summary}

Ever since the computer became an integral part of our life it has been obvious that every year faster, more useful computers are introduced into the marketplace. Even before computers became an everyday item, cars were. Every few years we see a new generation of Honda Civic or VW Golf equipped with features that make it (usually) a far better driving experience than the previous generation. This phenomenon of capital quality improvement is general and widespread and has been going on for a long while. As it happens, it also makes the job of official statisticians and growth accountants much more difficult. The reason is that prices at which transactions of new capital take place are not meaningful (in some respects) and can lead to misleading statements about the sources of economic growth. Unless, that is, one adjusts these prices to reflect the improvement in quality embodied in new capital goods.

While many statistical agencies expend significant efforts to adjust prices there is growing evidence that substantial biases remain. Since quality improvement is embodied in capital goods and comes mostly as a result of technological improvements, it is often referred to as embodied technological change (ETC).

In this paper, we expand on why this correction is essential in order to measure capital stock and output growth accurately. It is also essential for decomposing economic growth into its sources accurately. The lessons that we get from that discussion are that: 1) the output of investment-good producing sectors should be deflated by quality-adjusted prices. If not, its growth is likely to be underestimated. 2) Productive capital stocks (or more accurately, the service flows from capital that serve as input in production) should be constructed after deflating nominal investment flows by a quality-adjusted price index and depreciating old vintages with a rate that does not include quality change. Otherwise, the growth of capital stock is underestimated and its estimated contribution to growth is biased downward.

Our basic premise is that equipment price indexes in the euro area are insufficiently adjusted for quality improvement. In the empirical part of the paper we therefore substitute the official euro area investment price deflators for qualityadjusted price indexes series, based on US data. We do this for a much wider array of capital assets than ICT, which is usually the only category of assets corrected for in 
empirical work on the euro area. As a result, inferences about the role of capital accumulation and of different sources of technological change in euro area growth may usually be misleading. Indeed, we uncover substantial upward biases in the growth rates of euro area official price indexes. This has important implications for output growth itself as well as the sources of output growth. In particular, we ascribe a much more important role for capital in output growth and a correspondingly less important role for Total Factor Productivity. In itself, this reduction in the "extent of our ignorance" is very important. Furthermore, our results give rise to Embodied Technological Change as the key engine of growth in the euro area for the decades of the eighties and nineties. 


\section{Introduction}

Ever since the computer became an integral part of our life it has been obvious that every year faster, more useful computers are introduced into the marketplace. Even before computers became an everyday item, cars were. Every few years we see a new generation of Honda Civic or VW Golf equipped with features that make it (usually) a far better driving experience than the previous generation. This phenomenon of capital quality improvement is general and widespread and has been going on for a long while. As it happens, it also makes the job of official statisticians and growth accountants much more difficult. The reason is that prices at which transactions of new capital take place are not meaningful (in some respects) and can lead to misleading statements about the sources of economic growth. Unless, that is, one adjusts these prices to reflect the improvement in quality embodied in new capital goods.

While many statistical agencies expend significant efforts to adjust prices there is growing evidence that substantial biases remain. The study by Gordon (1990) has been instrumental in documenting and quantifying the extent of these biases. Gordon's quality-adjusted indexes have been used by some researchers (starting with Hulten, 1992) as a way of quantifying the extent of improvement in equipment quality. Since quality improvement is embodied in capital goods and comes mostly as a result of technological improvements, it is often referred to as embodied technological change (ETC). In section 2, we make the connection between the two concepts more precise in the context of a model with two productive sectors.

While the methodology of Hulten (1992) that compares Gordon's qualityadjusted prices to some un-adjusted prices is not the only one aimed at estimating ETC, we argue in Section 2 that it can be safely thought to provide conservative estimates (perhaps a lower bound) to the rate of growth of ETC. An advantage is that it provides estimates of capital quality improvement by disaggregated assets. Cummins and Violante (2002) have undertaken the very useful task of extrapolating Gordon's quality-adjusted price indexes series to recent years. While this is done with time-series rather than hedonic techniques, it still provides a useful basis for a much needed correction to official statistics.

In Section 3, we expand on why this correction is essential in order to measure capital stock and output growth accurately. It is also essential for decomposing 
economic growth into its sources accurately. The lessons that we get from that discussion are that: 1) the output of investment-good producing sectors should be deflated by quality-adjusted prices. If not, its growth is likely to be underestimated. 2) Productive capital stocks (or more accurately, the service flows from capital that serve as input in production) should be constructed after deflating nominal investment flows by a quality-adjusted price index and depreciating old vintages with a rate that does not include quality change. Otherwise, the growth of capital stock is underestimated and its estimated contribution to growth is biased downward.

Our main purpose in this paper is to apply these issues to euro area statistics. While substantial attention has been paid to issues relating to Information and Communication Technologies (ICT) investment expenditures, its appropriate deflation and its contribution to growth, the empirical work to date has not recognized that the issue of quality improvement concerns a much wider array of capital assets than ICT. As a result, inferences about the role of capital accumulation and of different sources of technological change in euro area growth may be misleading. Our basic premise is that equipment price indexes in the euro area are insufficiently adjusted for quality improvement. Our way to fix them is by applying to them the estimated bias adjustments of Cummins and Violante (2002), which are based on the work of Gordon (1990). We do not, however, apply the aggregate US index but rather use series disaggregated by equipment assets. Our underlying assumption is that since these capital assets are freely traded across the Atlantic, their prices should be rather similar in the US and in the euro area. However, we do allow for different composition of investment by asset at the industry level between the US and the euro area.

In Section 4, we present the results of this exercise. We calculate that growth rates of official price indexes for equipment and software in the euro area are biased upward substantially. In particular, the average annual quality bias is 3.7 percent in the 1980s and 4.4 percent in the 1990s. The increased bias in the 1990s is due to an acceleration in the growth rate of embodied technological change during that period in most categories of equipment- not just ICT. When adjusted for quality, productive capital stocks of equipment and software grow on average 3 percentage points faster annually- a doubling of their growth rates. Quality-adjusted output grows 0.46 percentage points faster annually. In terms of growth accounting, quality adjustment subtracts 11 percentage points from the share of TFP in output growth and adds them 
to the contribution of equipment stock. The share of $E \& S$ in output growth in the euro area over the period 1982-2000 increases from 19 percentage points to 30 percentage points when adjusted for quality. The share of embodied technological change in quality-adjusted output growth amounted to 46 percentage points over the period 1982-2000.

It is important to note that the approach of substituting US deflators for European ones can best be seen as illustrative of the magnitude of the problems created by insufficient quality adjustment in the European data. It is, however, not a solution. US deflators might differ from European deflators for a host of reasons apart from quality adjustment, including compositional effects in aggregate deflators and country-specific inflationary developments. In other words, our set of alternative deflators cannot be seen as an alternative official dataset, but it can be seen as an important stepping stone in that direction.

\section{A useful framework ${ }^{2}$}

An example might be useful before we write down the model. Suppose that only two goods are produced in the economy: computer boxes whose processing speed is $q_{t}$ Mhz and banking services. The number of computer boxes produced is denoted by $i_{t}$ and the number of banking transactions by $c_{t}$. The production of computers and banking services requires both computers and labor as input. The households in this economy derive utility only from banking services and not from using computers. Thus, computer production is channeled completely to investment expenditure.

As a result of some exogenous technological change $z_{t}$ the production of both computers and services becomes less costly over time in terms of resources. However, there is an additional force of exogenous technological change that increases the processing speed $q_{t}$ of computers each year. As a result of the higher processing speed a computer box of vintage $t$ is $\left(q_{t} / q_{t-1}\right)$ times more productive than a computer box of vintage $t-1$. In other words, a computer box of vintage $t$ is equivalent to

\footnotetext{
${ }^{2}$ The exposition in this section follows Solow (1960), Hornstein and Krusell (1996), Greenwood, Hercowitz, and Krussell (1997), Hercowitz (1998), and Sakellaris and Wilson (forthcoming). Ho and Stiroh (2001) also tackle some of the issues in this section. For clarity, we do not make a distinction here between structures and equipment investment, though Sakellaris and Wilson (forthcoming) argues that it is important empirically.
} 
$\left(q_{t} / q_{t-1}\right)$ computer boxes of vintage $t-1$ and we can write in efficiency units $\tilde{i}_{t}=i_{t} q_{t}$. This increased productivity may also be thought of as higher quality of the vintage $t$ computer and leads to obsolescence in the value of the vintage $t-1$ computer box by a factor of $\left(q_{t-1} / q_{t}\right)$, as we will see below.

\subsection{The two production technologies}

In order to formalize the concept of capitalembodied technological change we consider now a two-sector model of a closed economy without government where one sector produces investment goods $(\tilde{i})$ and the other sector produces consumption goods $(c)$. Each good is produced using capital $(\tilde{k})$ and labor $(l)$ as inputs according to the following production functions:

$$
\begin{gathered}
\tilde{i}_{t}=z_{t} q_{t} \tilde{k}_{\tilde{k}, t}^{\alpha} l_{\dot{i}, t}^{1-\alpha} \\
c_{t}=z_{t} \tilde{k}_{c, t}^{\alpha} l_{c, t}^{1-\alpha}
\end{gathered}
$$

where $z$ is an index of technology representing Hicks-neutral technological change that is common to both sectors whereas $q$ is an index of technology that is specific to the investment goods sector . A " " denotes that the variable is defined in efficiency units. For simplicity, $\alpha$, the elasticity of output with respect to capital is assumed to be the same in both sectors. ${ }^{3}$

The stock of capital (also in efficiency units) is defined as follows:

$$
\tilde{k}_{t}=(1-\delta) \tilde{k}_{t-1}+i_{t} q_{t}
$$

where $\delta$ is the (geometric) rate of physical decay. This captures the decay in productive ability due to wear in use and it has also been labeled physical decay or deterioration. This rate is different than the rate of economic depreciation to be defined below. ${ }^{4}$ Note that in order to construct the capital stock we need to adjust each vintage of investment expenditures for quality change that is due to capital-embodied technological change.

\footnotetext{
${ }^{3}$ Hornstein and Krusell (1996) show the implications of allowing $\alpha$ to vary across sectors.

${ }^{4}$ The quantity $1-\delta$ can be thought of as the ratio of the marginal product of a vintage of capital to that of the following year's vintage of capital.
} 
Essentially, what is being modeled here is the situation where the production of investment goods is subject to more rapid Hicks-neutral technological change than that of the rest of the goods. As a result, the marginal unit of investment goods uses an ever-decreasing amount of the economy's resources compared to what is needed to produce the marginal unit of a consumption good. This decrease in the relative marginal costs will show up in a corresponding decrease in relative prices under perfect competition. ${ }^{5}$ Even though $\tilde{i}_{t}$ denotes the whole capital goods sector here the model may be used to study any situation where there is a stark difference in the rates of technological change between different sectors in the economy as for example between Information and Communication Technologies equipment and the rest of the economy.

\section{Definition and discussion of embodied technological change}

We define as capitalembodied technological change (ETC), or capital quality improvement, the phenomenon described in the above two equations where Total Factor Productivity (TFP) grows faster in the investment goods sector than in the consumption goods sector. This technological change is embodied in capital goods in the sense that was articulated in the above example. The index $q$ measures computer processing speed or some other characteristic of the capital good that leads to higher efficiency of the capital good in the production of other goods. It is also embodied in the sense that the economy can only take advantage of this part of technological progress by producing and using new capital goods. The economy described by equations (1) and (2) enjoys a higher rate of growth of TFP the more that it invests in new capital. There is also a fundamental distinction between different vintages of capital goods.

However, an alternative interpretation may be given to the above two equations. The index $q$ may not describe increases in the quality of capital goods but rather increased number of physical units produced with given resources. Instead of having the computer boxes produced embody higher processing speed indexed by $q$, we have the number of computer boxes produced using a given amount of resources

\footnotetext{
${ }^{5}$ The assumption of perfect competition is a departure from reality. The existence of markups, of course, puts a wage between price and marginal costs that may influence any inference of the rate of ETC based on the decline in the relative prices of the two goods. However, as long as there is no trend in the ratio of the markups in the two sectors the measurement error generated would not be important.
} 
grow with $q$ while their processing speed remains the same. In the above simple model, these two interpretations are indistinguishable while clearly only the first one conforms to the concept of quality embodied in a new capital good.

It seems that the first interpretation is closer to what has been for most capital assets. For example, regarding ICT capital goods, Jorgenson (2001) has argued that rapid increases in the efficiency of semiconductors led to rapid increases in the quality of ICT capital goods without offsetting increases in their production costs. Since there are no intermediate inputs in the model provided here these quality changes show up directly in the final goods. Of course, a more satisfying model would include intermediate goods as well.

It is clear from the above discussion that the concept of embodied technological change is intimately linked with growth in capital goods quality. However, the setup here is too simple to characterize adequately all the important issues related to quality change. For example, increased quality is assumed here to arise costlessly to the economy whereas in a more realistic model it would have resource costs. If it is costly research that leads to higher quality then one would need to include that in the model as well. This research cost might be once-and-for-all or a recurring one.

\subsection{Estimating Embodied Technological Change}

\section{Price-based Estimates}

Assume that all factors of production are perfectly mobile across sectors and that perfect competition holds in all markets. Then, as a result of factor price equalization, the price of investment goods relative to consumption goods is:

$$
P_{t}^{\tilde{i}} / P_{t}^{c}=1 / q_{t} .
$$

Thus, one may compute the rate of growth of capital-embodied technological change from the rate of decline in the relative price of investment goods. This result forms the basis of the price-based approach to measuring embodied technological change. Note, however, that the price that appears in the numerator is that for efficiency-adjusted (or quality-adjusted) investment goods and not the transaction price of investment goods.

Gordon (1990) is a major study aimed at correcting mismeasurement in equipment price indexes due to quality change. He uses a combination of hedonic techniques and matched-model methods to provide quality-adjusted price indexes for 
22 types of equipment and their components. Hulten (1992) is the first to use these series in order to identify embodied technological change. He constructs a single aggregate index from Gordon's indexes as well as one for the corresponding price indexes published by BLS. Taking the ratio of the two, he calculates the average annual growth rate of embodied technological change to be 3.44 percent for U.S. manufacturing during 1949-1983. Various papers have followed Hulten (1992) in using Gordon's data but differed in the methodology employed. Greenwood et al. (1997) argue that the baseline index for comparison should be the implicit price deflator for non-durable consumption goods. This has very little effect on their estimate of embodied technological change. A serious impediment for current work is that Gordon's series ends in 1983.

Cummins and Violante (2002) have undertaken the important task of updating these asset-specific price indexes to 2000 . They do so by means of extrapolation using a time-series forecasting technique for the quality adjustment for each of the capital assets in the Gordon (1990) study. They estimate that the 1990's brought an acceleration in ETC as measured by the price-based approach. In particular, for US manufacturing their estimated rate of ETC jumped from about 4 percent in the 1970's and 1980's to about 5.6 percent in the 1990's (See their Table III, p. 261).

However, the comparison of the above two price indexes is not the only way to estimate the rate of growth of capital quality. An alternative approach relies on data on produced output and utilized inputs.

\section{Production-based Estimates}

Bahk and Gort (1993) provide estimates using Nelson's (1964) variant of Solow's (1960) embodiment model. They study a sample of young manufacturing plants and find that a 1-year drop in average age is associated with between a 2.5 and a 3.5 percent rise in the plant's gross output (See their Table 1 and p. 571). Assuming a one-sixth share weight for capital in the production function of gross output, these results correspond to a 15-21 percent annual rate of growth of embodied technological change. This is three to four times higher than the baseline price-based estimates discussed above.

Sakellaris and Wilson (forthcoming) implement a more direct approach based on equations (1) and (2). They: 
1. Deflate output and investment by a price index that does not adjust for quality change.

2. Apply depreciation adjustments to capital that capture physical decay but not quality change.

3. Allow the marginal productivity of each vintage, $q_{t}$, to be freely estimated.

Their estimated series of $q_{t}$ provides an estimate of ETC of about 12 percent annually for the years 1972-1996.

\section{Structural Model-Based Estimates}

Hobijn (2000) measures embodied technological change by fitting a simple stochastic vintage capital model to aggregate US data. After calibrating model parameters he filters out the implied path of embodied technological change and estimates the rate of growth of embodied technological change at about $4 \%$ for the period 1975-1999. This estimate, however, is biased downward because, as the author admits, the depreciation rate used in this calibration is too high.

A related approach is taken in Hobijn et al. (2002). They modify the neoclassical model of investment with convex adjustment costs to include embodied technological change. They then estimate the Euler equations for investment using data for 4-digit US manufacturing industries. Their estimates of the rate of embodied technological change for equipment range between $9.5 \%$ and $32.6 \%$. The stark difference in estimates between the two papers may be due to the higher level of aggregation of the data in the former. Earlier papers using a production-side approach have already concluded that aggregation biases the rate of embodied technological change downward (see e.g. Wickens, 1970, You, 1976, and McHugh and Lane, 1987).

\section{Comparison of Estimates}

It should be clear from the above discussion that there is a high degree of uncertainty about the magnitude of capital quality growth. The price-based estimates set the average annual growth rate of ETC at about 3-6 percent depending on the time period. The production-based estimates set it at about 12 percent or even higher. 
Structural-model based estimates do not tip the scale either way as they range from 4 percent to over 30 percent.

Aggregate estimates based on prices may be downward biased because Gordon was only able to create new price indexes for durable goods for which sufficient data on model characteristics and prices existed. The Sears catalog was the primary source of this data. For a large number of goods there simply was no data. Production-based estimates, on the other hand, are likely to be upward-biased due to simultaneity. Since firms with higher TFP will invest more and, thus, have younger capital stock it will seem that newer vintages contribute more to productivity than older ones. Structural model-based estimates may have biases due to model misspecification but it is not clear whether the direction should be positive or negative.

\section{Lessons for measurement}

\subsection{Productive capital stocks}

From the simple model above it is clear that there are two consistent, though not equivalent, ways of constructing productive capital stocks. ${ }^{6}$ The first is a qualityadjusted capital stock, $\tilde{k}_{t}$, as specified in equation (3). Here it is important to note that the investment flows are expressed in efficiency units and all past investment flows are adjusted by a rate of physical decay, $\delta$, which is assumed to be geometric:

$$
\tilde{k}_{t}=i_{t} q_{t}+(1-\delta) i_{t-1} q_{t-1}+\ldots+(1-\delta)^{t} i_{0} q_{0} .
$$

An alternative, more conventional, way of constructing the capital stock is:

$$
k_{t}=i_{t}+(1-\delta) \frac{q_{t-1}}{q_{t}} i_{t-1}+\ldots+(1-\delta) \frac{q_{0}}{q_{t}} i_{0}
$$

As a result, $\tilde{k}_{t}=q_{t} k_{t}$. We will call $k_{t}$ the hybrid capital stock as it contains only partial adjustment for quality. It is clear that the difference in the growth rates of

\footnotetext{
${ }^{6} \mathrm{We}$ abstract here from issues relating to aggregation of different capital assets into the flow of capital services (see Jorgenson and Griliches, 1967). In our empirical work, however, we deal with these
} 
the two capital stocks is the rate of growth of embodied technological change (or of quality), i.e.

$$
\frac{\dot{\tilde{k}}_{t}}{\tilde{k}_{t}}=\frac{\dot{k}_{t}}{k_{t}}+\frac{\dot{q}_{t}}{q_{t}}
$$

\section{Depreciation rates:}

Hulten and Wykoff (1981) measure economic depreciation rates of capital assets by estimating the change in the value of that asset associated with aging. This change contains two effects: one is a pure age effect arising from use, wear and tear and the second one is a vintage effect arising from obsolescence due to improvements in the quality embodied in the assets. The first effect is called physical decay while the second one obsolescence or quality change. The rate of economic depreciation is a combination of these two:

$$
1-d=(1-\delta) \frac{q_{t-1}}{q_{t}}
$$

Hall (1968) has demonstrated the fundamental inability to separately identify physical decay and embodied technological change with only a cross-sectional set of used asset prices. This fundamental identification problem implies that either physical decay or embodied technological change must be "observed" in some way. This is where equation (4) comes in handy. It identifies separately the term $\frac{q_{t-1}}{q_{t}}$ and, thus, $(1-\delta)$, given the Hulten-Wykoff estimates for $1-d .^{7}$

The Hulten-Wykoff estimates of economic depreciation or their variants are used extensively in the construction of productive capital stocks. When the investment flows for capital assets are adjusted for quality change a problem arises. In a sense, these assets are "double-adjusted" for quality change when constructing capital stocks

\footnotetext{
issues.

${ }^{7}$ Reality is more complicated, as usual. There is endogenous scrapping of (old) vintages of capital induced by obsolescence. Such scrapping may occur because there is a fixed operational cost (Whelan, 2002) or because workers and machines are used in fixed proportions. The estimate of $1-d$ includes the effect of this scrapping. The ratio $\frac{1-d}{\frac{q_{t-1}}{q_{t}}}$ still provides the appropriate depreciation rate for
} 
$\tilde{\tilde{k}}_{t} \cdot{ }^{8}$ This leads to deviations between $\tilde{k}_{t}$ and $k_{t}$ as shown below:

$$
\tilde{\tilde{k}}_{t}=q_{t} i_{t}+(1-\delta) \frac{q_{t-1}}{q_{t}} i_{t-1} q_{t-1}+\ldots+(1-\delta)^{t} \frac{q_{0}}{q_{t}} i_{0} q_{0}
$$

This "double-adjusted" capital stock, $\tilde{\tilde{k}}_{t}$, grows slower than the correctly "quality-adjusted" capital stock, $\tilde{k}_{t}$. We will see below the implications for growth accounting exercises of this kind of measurement error. There is a second way to construct capital stocks incorrectly in the presence of embodied technological change: not to adjust for quality change at all. Define this 'quality-unadjusted' capital stock, $k_{t}$, as follows

$$
\hat{k}_{t}=i_{t}+(1-\delta) i_{t-1}+\ldots+(1-\delta)^{t} i_{0}
$$

\subsection{Real output growth}

A major conceptual step toward being able to do growth accounting is figuring out how to construct aggregate real output. The approach followed by the Bureau of Economic Analysis (BEA) in constructing the National Income and Product Accounts (NIPA) is to adjust all sectoral output for quality growth before aggregation. This follows the framework of Domar (1961) and Jorgenson (1966) and has also been advocated by Hulten (1992) and Licandro et al. (2002). Written as a Divisia index aggregate real output, $Y_{t}$, is: ${ }^{9}$

$$
\frac{\dot{Y}_{t}}{Y_{t}}=\left(1-\mu_{t}\right) \frac{\tilde{i}_{t}}{\tilde{i}_{t}}+\mu_{t} \frac{\dot{c}_{t}}{c_{t}}
$$

where $\mu_{t}$ is the fraction of aggregate capital stock, measured in efficiency units, devoted to investment goods production. Equivalently, $\mu_{t}$ is the ratio of the output of the investment sector, $\tilde{i}$, to total output measured in terms of consumption,

$$
\mu_{t}=\frac{i_{t}}{c_{t}+i_{t}}=\frac{P_{t}^{i} i_{t}}{P_{t}^{c} c_{t}+P_{t}^{i} i_{t}}
$$

As shown by the last equality, the weight on each sector's growth of output is the share of the sector's nominal output in aggregate nominal output.

constructing productive capital stocks but is not a pure measure of physical decay due to wear and tear. ${ }^{8}$ Oliner (1993) and Gort and Wall (1998), among others, have brought attention to this point.

${ }^{9}$ Actually, the NIPA employ the Fisher Ideal Index to create chain-weighted aggregates. 
Decomposing the growth rate of aggregate real output into its sources we have the

$$
\frac{\dot{Y}_{t}}{Y_{t}}=\left(1-\mu_{t}\right) \frac{\dot{z}_{t}}{z_{t}}+\mu_{t}\left(\frac{\dot{z}_{t}}{z_{t}}+\frac{\dot{q}_{t}}{q_{t}}\right)+\alpha \frac{\tilde{k}_{t}}{\tilde{k}_{t}}+(1-\alpha) \frac{\dot{l}_{t}}{l_{t}}
$$

This is the Domar aggregation scheme that Hulten (1978) shows obtains when there are intermediate inputs. As there are no intermediate inputs in our model the shares here sum to one. The TFP obtained after applying the growth accounting decomposition is a weighted average of the TFP in each of the two sectors with the weights given above.

\section{What if aggregate output were not adjusted for quality?}

In that case one can write total output in terms of consumption goods, $y_{t,}$ as:

$$
\frac{\tilde{i}_{t}}{q_{t}}+c_{t}=i_{t}+c_{t}=y_{t}=z_{t} \tilde{k}_{t}^{\alpha} l_{t}^{1-\alpha}
$$

As a reminder, $i_{t}$, in the above expression denotes the investment goods measured in terms of consumption goods (i.e. unadjusted for quality) and $\tilde{k}$ is defined in efficiency units (i.e. adjusted for quality). The last equality arises because capital labor ratios are equalized across sectors and the sectoral production functions are homogeneous of degree one. It is easy to show that equation (14) may be written equivalently as:

$$
y_{t}=z_{t} q_{t}^{\alpha} k_{t}^{\alpha} l_{t}^{1-\alpha}
$$

where $k_{t}$ is defined in (6) or equivalently:

$$
k_{t}=\left(\frac{1-\delta}{\frac{q_{t}}{q_{t-1}}}\right) k_{t-1}+i_{t}
$$

The bias due to the absence of capital quality adjustment is

$$
\frac{\dot{y}_{t}}{y_{t}}-\frac{\dot{Y}_{t}}{Y_{t}}=-\mu_{t}\left(\frac{\dot{q}_{t}}{q_{t}}\right) \text {. }
$$

In other words, real output growth is underestimated by a term equal to the rate of embodied technological change multiplied by the share of investment in nominal output. 


\subsection{Growth accounting}

For all measurement exercises in this paper we define the quantity of aggregate output in terms of a Tornqvist index: ${ }^{10}$

$$
d \log \left(Y_{t}\right)=\bar{\mu}_{t} d \log \left(\tilde{i}_{t}\right)+\left(1-\bar{\mu}_{t}\right) d \log \left(c_{t}\right),
$$

where $\mu_{t}$ is defined in equation (12) to be the share of investment goods in mminal output and $1-\mu_{\mathrm{t}}$ represents the average share between periods $\mathrm{t}$ and $\mathrm{t}-1$. It is clear that the contribution of TFP to growth in measured output is the weighted average of technological growth rates in the two sectors with the weights given in (18). The impact of the production and use of capital goods on output growth in the economy is twofold. The use of new capital as input in production contributes to output growth through the term

$$
\alpha\left[\bar{\mu}_{t} d \log \left(\tilde{k}_{\tilde{i}, t}\right)+\left(1-\bar{\mu}_{t}\right) d \log \left(\tilde{k}_{c, t}\right)\right]
$$

while the production of capital goods contributes through the term

$$
\bar{\mu}_{t}\left[d \log \left(q_{t}\right)+d \log \left(z_{t}\right)\right] .
$$

Note that the impact of embodied technological change on output growth is given by:

$$
\left\{\bar{\mu}_{t} d \log \left(q_{t}\right)\right\}+\alpha\left\{\bar{\mu}_{t} d \log \left(\frac{\tilde{k}_{\tilde{i}, t}}{\hat{k}_{i, t}}\right)+\left(1-\bar{\mu}_{t}\right) d \log \left(\frac{\tilde{k}_{c, t}}{\hat{k}_{c, t}}\right)\right\}
$$

The first component of the sum is the contribution of embodied technologic al change to aggregate TFP growth through the production of capital goods. The second component is the contribution of capital accumulation (the use of capital in production). In this second component, embodied technological change contributes through the growth of effective capital over and above what would have been the case if there were no quality growth. ${ }^{11}$

\footnotetext{
${ }^{10}$ This index, in general, gives similar results to the Fisher Ideal Index that BEA use to produce the official NIPA.

${ }^{11}$ Hulten (1992) provides a clear discussion of this decomposition. Greenwood et al. (1997), however, point out that this calculation is likely to underestimate the impact of embodied technological change on output growth as it does not adjust for the endogenous response of investment to changes in the rate of quality growth and the ensuing drops in relative prices.
} 


\section{Growth accounting without quality adjustment}

Under these circumstances measured aggregate output growth is lower as shown above. It is easy to show that in this case estimated TFP growth is $d \log \left(z_{t}\right)+\alpha d \log \left(q_{t}\right)$. The estimated contribution of capital accumulation to output growth is

$\alpha\left[\bar{\mu}_{t} d \log \left(k_{i, t}\right)+\left(1-\bar{\mu}_{t}\right) d \log \left(k_{c, t}\right)\right]=\alpha\left[\bar{\mu}_{t} d \log \left(\tilde{k}_{\tilde{k}, t}\right)+\left(1-\bar{\mu}_{t}\right) d \log \left(\tilde{k}_{c, t}\right)\right]-\alpha d \log \left(q_{t}\right)$.

As shown in (7), the result is to bias downward the growth of effective capital stocks by an amount equal to the growth rate of embodied technological change. This translates into a lower estimated contribution to economic growth.

\section{Empirical results}

\subsection{Quality-adjusted price index for investment}

Investment price deflators in euro area countries are generally believed to be insufficiently quality-adjusted. In particular, it is a widely debated question whether more sophisticated, including hedonic techniques are preferable to more conventional methods often used in euro area countries. Hedonic methods have been designed to permit quality and price changes to be captured with greater accuracy (i.e. a deflation technique based on a regression of the prices of a basket of goods on a set of qualities or characteristics of those goods, to identify price changes due to quality changes). Although Aizcorbe et al. (2000) showed that, under certain conditions, a conventional matched model approach can yield similar results to hedonics, in practice, countries applying more conventional techniques record, for example, smaller price declines in ICT goods than countries applying the hedonic technique. Therefore, the US-based deflator for information equipment is often applied to nominal European national accounts data (e.g. Schreyer 2001, Van Ark et al 2002, Vijselaar and Albers 2003). 
In this paper, we follow a similar approach, not only for IT hardware, but also for other equipment and software (E\&S) categories. In particular, we use the data underlying Cummins and Violante (2002). Cummins and Violante (CV) extended the Gordon (1990) dataset of constant-quality equipment price indexes. ${ }^{12}$ This dataset contains price indexes for 25 investment goods. Since our data for the euro area are not as finely disaggregated into E\&S assets we aggregate the CV deflators to four asset categories: IT hardware, communication equipment, transport equipment, and other machinery and equipment. The appendix provides more details on how we performed the aggregation. For software we continue using the original euro area deflators, as the US series are not quality-adjusted and, therefore, would not be superior to the European ones for this investment category.

It is important to note that the approach of substituting US deflators for European ones can best be seen as illustrative of the magnitude of the problems that the lack of quality adjustment in the European data poses. It is, however, not a solution. It is all too obvious that US deflators might differ from European deflators for a host of reasons apart from quality adjustment, including compositional effects in aggregate deflators and country-specific inflationary developments. In other words, our set of alternative deflators cannot be seen as an alternative official dataset, but it can be seen as an important stepping stone in that direction.

By comparing the growth rate of the quality-adjusted price index for $\mathrm{E} \& \mathrm{~S}$ to the original price index for $E \& S$ based on the euro area national accounts deflators, we can compute the implied quality bias in the original price index. This bias arises because the $\mathrm{CV}$ quality-adjusted deflators decline on average more rapidly than the original deflators. According to our estimates the average annual quality bias in the euro area was 3.7 percent in the 1980s, increasing to 4.4 percent in the 1990s. This increase mainly reflects the growing share of IT hardware in E\&S investment, for which the quality bias is relatively large. While the broad developments are reflected

\footnotetext{
${ }^{12}$ Gordon used a matched-model method to construct his database, not hedonic techniques. However, he met the conditions as identified later by Aizcorbe et al. to get similar results as when applying hedonic methods.
} 
across sectors, there are clear differences in the degree of the bias at the sectoral level (see Chart 1 below and Table 1 in the Annex). The quality bias is highest in the sectors investing most in other machinery and equipment, and/or in IT hardware.

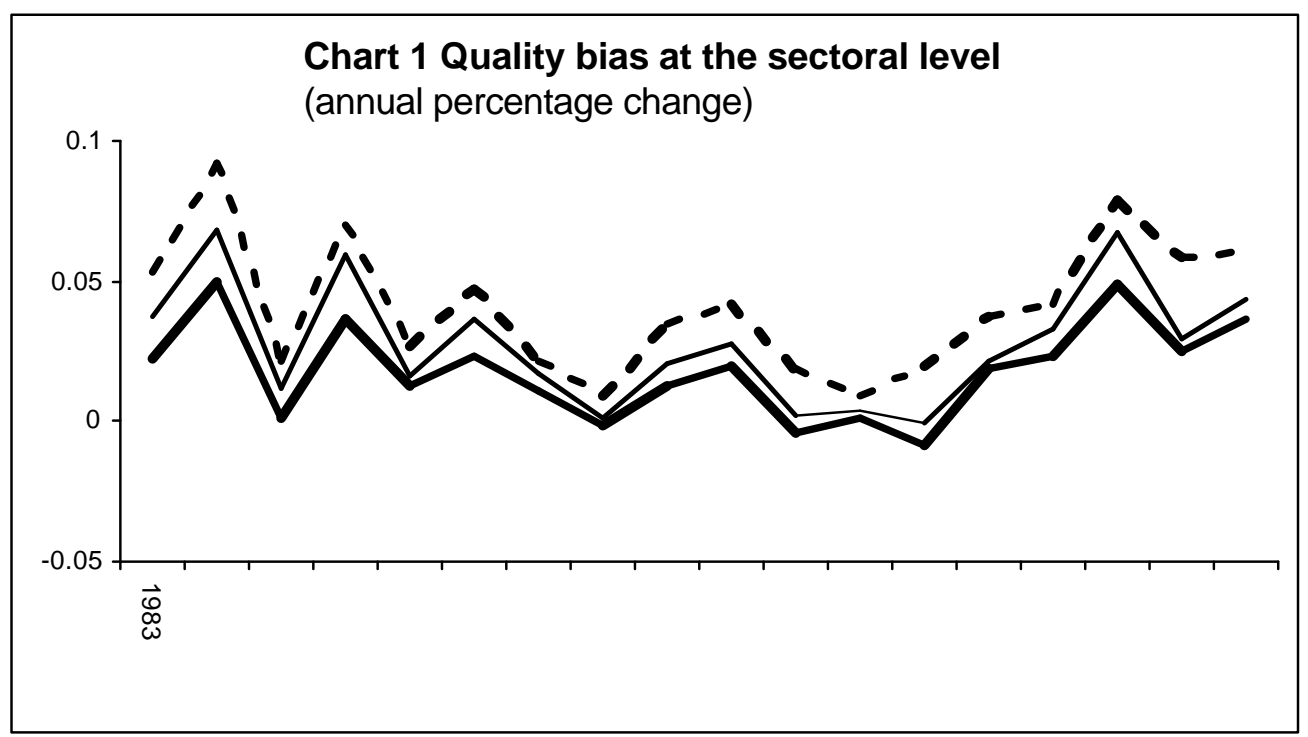

Following, Cummins and Violante (2002), we construct an index of the state of embodied technology, q. As argued earlier, under certain conditions, we can identify the index $\mathrm{q}$ as the relative price of consumption over investment:

$q_{t}=P_{t}^{\tilde{i}} / P_{t}^{c}$

where $P_{t}^{c}$ is the overall private consumption price deflator from the national accounts.

When $P_{t}^{\tilde{i}}$ is an aggregate price index for E\&S (the CV based index), $\mathrm{q}_{\mathrm{t}}$ indexes aggregate technology. Otherwise, it refers to specific sectors or capital assets.

The aggregate rate of embodied technological change grows rapidly, at an annual average rate of $4.7 \%$ in the $1980 \mathrm{~s}$ and of $6.0 \%$ in the 1990s. These results are similar to those found by $\mathrm{CV}$ for the US. This is not surprising as the underlying asset price deflators are the same and the asset composition at broad levels of aggregation must be rather similar in the US and the euro area.

Table 1 shows the rate of technological change for each of the five E\&S categories we 
distinguish separately. Not surprisingly the largest gains are in IT hardware. Software was the only category to show a deceleration from the 1980s to the 1990s. Although people are generally worried about ICT, our estimates show that ignoring other equipment categories may be a serious mistake.

From the sectoral data, it is clear that technological change was rather stable across sectors up to 1995, but accelerated thereafter in line with an increased investment in IT hardware and communications equipment after 1995 (Chart 2 below and Table 2 in the Annex). An interesting fact that is evident in this Chart is that sectors leading in ETC jumped further ahead from the middle of the pack in the 1990s. By 2000 the distance between the $90^{\text {th }}$ percentile of the distribution and the median, in terms of ETC, is the largest it has been throughout the two preceding decades.

Table 1. Embodied technological change

\begin{tabular}{l|ccc|}
\multicolumn{1}{c}{ Information equipment } & $\mathbf{1 9 8 1 - 1 9 9 0}$ & $\mathbf{1 9 9 1 - 2 0 0 0}$ & $\mathbf{1 9 8 1 - 2 0 0 0}$ \\
\cline { 2 - 4 } Software & 0.10 & 0.13 & 0.11 \\
Communication equipment & 0.04 & 0.02 & 0.03 \\
Other Machinery and equipment & 0.08 & 0.12 & 0.1 \\
Transport equipment & 0.04 & 0.06 & 0.05 \\
Equipment & 0.03 & 0.03 & 0.03 \\
E\&S & & & \\
& 0.05 & 0.06 & 0.05 \\
& 0.05 & 0.06 & 0.05 \\
\hline
\end{tabular}

(average annual percentage change)

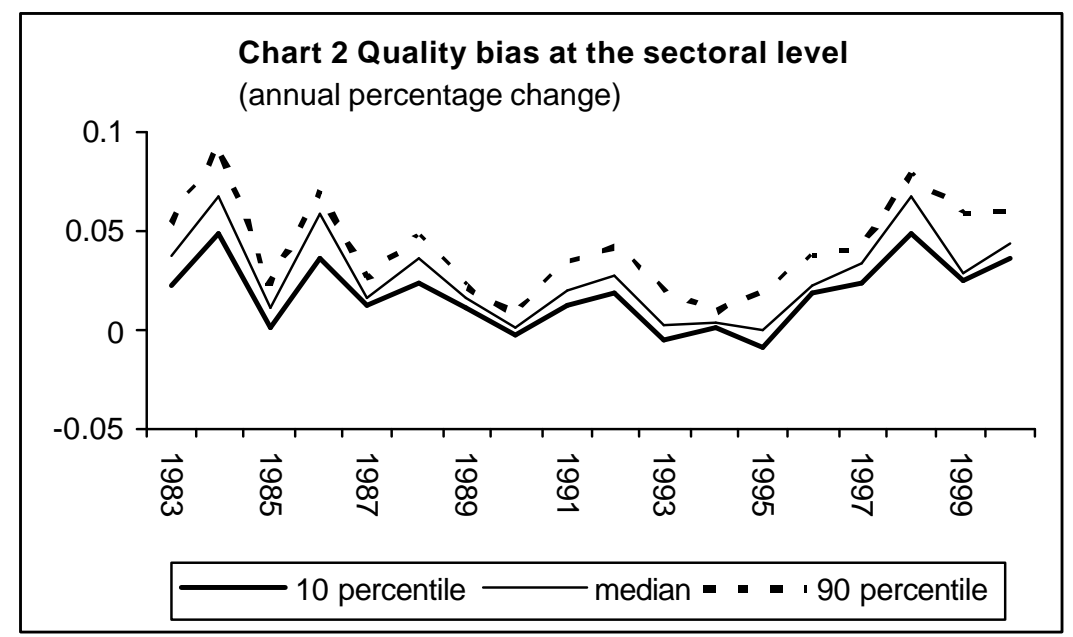




\subsection{Quality-adjusted E\&S capital stock and output}

We use the following formula to construct the capital stocks:

$\mathrm{k}_{\mathrm{jt}}=\sum_{b=0}^{b=m j}\left(1-\delta_{\mathrm{j}}\right)^{\mathrm{b}} \mathrm{i}_{\mathrm{j}(\mathrm{t}-\mathrm{b}),}$,

where $\mathrm{i}_{\mathrm{jb}}$ represents real investment at time $\mathrm{b}$ in capital good $\mathrm{j} ;\left(1-\delta_{\mathrm{j}}\right)^{\mathrm{b}}$ is the efficiency at time $t$ of investments in capital good $\mathrm{j}$ undertaken at time $\mathrm{t}-\mathrm{b}$, and $\mathrm{m}_{\mathrm{j}}$ is the average service life of capital good j. When constructing conventional capital stocks (where original deflators are used) we use measures of economic depreciation rates, while when constructing quality-adjusted capital stocks (where CV-based deflators are used) we use measures of physical decay rates for $d_{j}$. In line with BEA we use a geometric pattern of depreciation/decay.

We calculate physical decay rates by removing the quality-change component from the economic depreciation rate using our estimates of asset-specific quality improvement. More specifically, economic depreciation is the change in the value of an asset as it ages. The pure impact of ageing results from physical decay due to wear and tear. There is, however, an additional vintage effect that reflects obsolescence due to the change in the relative price of the asset. The physical decay rate can thus be calculated from the following formula:

$\delta_{\mathrm{j}, \mathrm{t}}=1-\left(1-\mathrm{d}_{\mathrm{j}, \mathrm{t}}\right) *\left(\mathrm{q}_{\mathrm{j}, \mathrm{t}} / \mathrm{q}_{\mathrm{j}, \mathrm{t}-1}\right)$

where $\delta$ is physical decay, $\mathrm{d}$ is economic depreciation and $\mathrm{q}$ is the relative price of an asset $\mathrm{j}$.

When embodied technology improves, physical decay, $\delta$, is lower than economic depreciation, $d$. Using the identity above, we calculate the physical decay rates and use these to construct our quality-adjusted capital stocks. Chart 4 shows the physical decay and the economic depreciation rate of E\&S as an aggregate. ${ }^{13}$ The economic depreciation rate is slightly increasing due to increased investment in assets with high

\footnotetext{
${ }^{13}$ As suggested by Whelan (2002), to derive an aggregate depreciation rate we aggregate asset-specific rates using as weights their shares in nominal capital stock.
} 
depreciation rates, in particular IT hardware and software. Like CV, we find the physical decay rate to be rather volatile from year to year. In calculating the capital stocks, we therefore use the average of the physical decay rates across years.

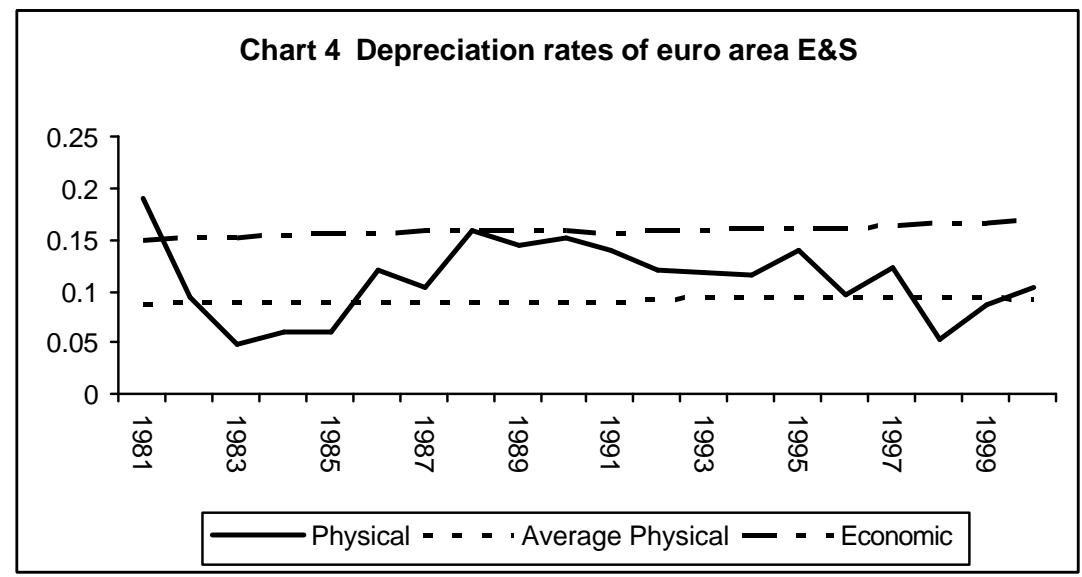

From Table 2 it is clear that the annual average growth rate of quality adjusted E\&S capital stock where we use physical decay and CV-based deflators is about twice as high as the original E\&S, where we use BEA style economic deprecation and nonquality adjusted deflators. The absolute difference in growth rates for the capital stock of IT hardware is larger. The decline in growth rate from the 1980s to the 1990s can be attributed in large part to the developments in the early 1990s, around the trough in economic growth when investment growth was relatively low.

Table 2 Quality-adjusted and original capital stocks (annual percentage change)

\section{E\&S quality adjusted E\&S original difference}

IT hardware quality-adjusted IT hardware original difference

\begin{tabular}{|ccc|}
\hline $1982-1990$ & $1991-2000$ & $1982-2000$ \\
\hline 0.05 & 0.06 & 0.06 \\
0.03 & 0.03 & 0.03 \\
0.02 & 0.03 & 0.03 \\
& & \\
0.15 & 0.12 & 0.14 \\
0.1 & 0.09 & 0.09 \\
0.05 & 0.04 & 0.04 \\
\hline
\end{tabular}

After this adjustment of capital input, we now turn to calculating a quality-adjusted output growth series. To do so we use a Tornquist index on the growth rates of real investment output and real consumption (i.e. non-E\&S output). The share used is the ratio of nominal investment to nominal output. As expected, the quality-adjusted 
output growth is higher than the original output growth (see Chart 5). Note that quality adjustment has a substantial effect on real output growth in 1981-87, with an annual average difference of 0.4 percentage point, and 1994-2000, with an annual average difference of 0.7 percentage point, but not for the years in between, when the rate of technological change was relatively low, as was the equipment investment rate.

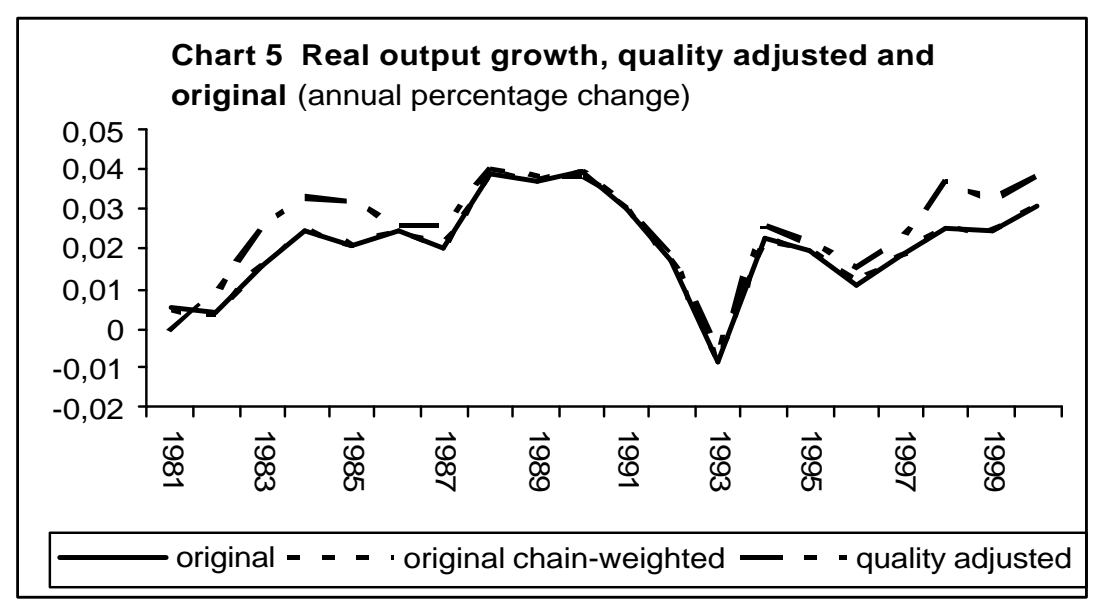

\subsection{Contribution of quality-adjusted capital to economic growth}

To assess the contribution of capital to economic growth and to estimate the development of TFP, we carry out a standard growth accounting covering the period 1982-2000. The growth accounting framework was pioneered by Solow (1957) and further developed by Jorgenson and his associates (e.g. Jorgenson and Griliches, 1967; Jorgenson et al. 1987). The framework used here is similar to that used in Oliner and Sichel (2000).

In a growth accounting framework, the growth rate of output $(\dot{Y})$ is equal to the weighted growth rates of labour input $(\dot{L})$ and capital input $(\dot{K})$, plus growth in total factor productivity $(\dot{T F P})$. The following formulas were used here:

$\dot{Y}=\mathrm{a}_{\mathrm{L}} \dot{L}+\sum_{j} \mathrm{a}_{\mathrm{Kj}} \dot{K}_{\mathrm{j}}+T \dot{F} P$ 
which, after some rearranging, and assuming that $\sum_{j} \mathrm{a}_{\mathrm{Kj}}=1-\alpha_{\mathrm{L}}$, yields the following expression for ALP:

$\dot{Y}-\dot{L}=\sum_{j} \mathrm{a}_{\mathrm{Kj}}\left(\dot{K}_{\mathrm{j}^{-}} \dot{L}\right)+\dot{T F P}$

Time subscripts have been suppressed for simplicity of notation. Labour input growth is measured in total hours worked. Due to data limitations, no adjustment has been made for the quality of labour in this exercise.

As to capital inputs, in all, six categories of capital have been distinguished: our previously distinguished five categories of $\mathrm{E} \& \mathrm{~S}$ plus the stock of non-residential construction. The latter stock is assumed to be unaffected by quality biases. Depreciation and efficiency decay are derived consistently, using a geometric rate of decline. The sum of the shares of the various types of capital is assumed to be equal to 1- $\alpha_{\mathrm{L}}$, a standard assumption in this kind of exercise reflecting constant returns to scale. The shares of the different types of assets in total capital input are based on the user cost of capital, i.e. the gross rate of return that must cover the internal rate of return (assumed common to all capital), the depreciation rate, and the capital gain/loss of the specific capital good. Tax considerations were not taken into account, but the impact of taxes on the user cost of capital is assumed to be captured by the internal rate of return.

The results of our estimates are shown in the Tables below. From these tables it is clear that the contribution of quality-adjusted capital is much higher than previously calculated. Interestingly, this does not relate only to IT hardware, but most importantly to other machinery and equipment. Due to the effects of quality adjustment in output, TFP growth hardly differs from the original case in absolute terms. However, as a percentage of total output it declines: Quality adjustment subtracts 11 percentage points from the share of TFP in output growth and adds them to the contribution of equipments stock. As a memory item ETC is identified in Table 5, the contribution to growth of ETC is substantial, and even increased from the 1980s to the 1990 s, as a share of total output from $40 \%$ to over $50 \%$. 
As a final result of our exercise, we decomposed the sources of economic growth in percentages of overall output growth along the lines of ETC. Again it is clear that ETC is a major contribution to growth, with both the quality of capital and inve stment specific TFP increasing from the 1980s to the 1990s. As a final note, it is interesting to see that the investment specific component of TFP increased although overall TFP decreased.

Table 5 Contributions to output growth (percentage points)

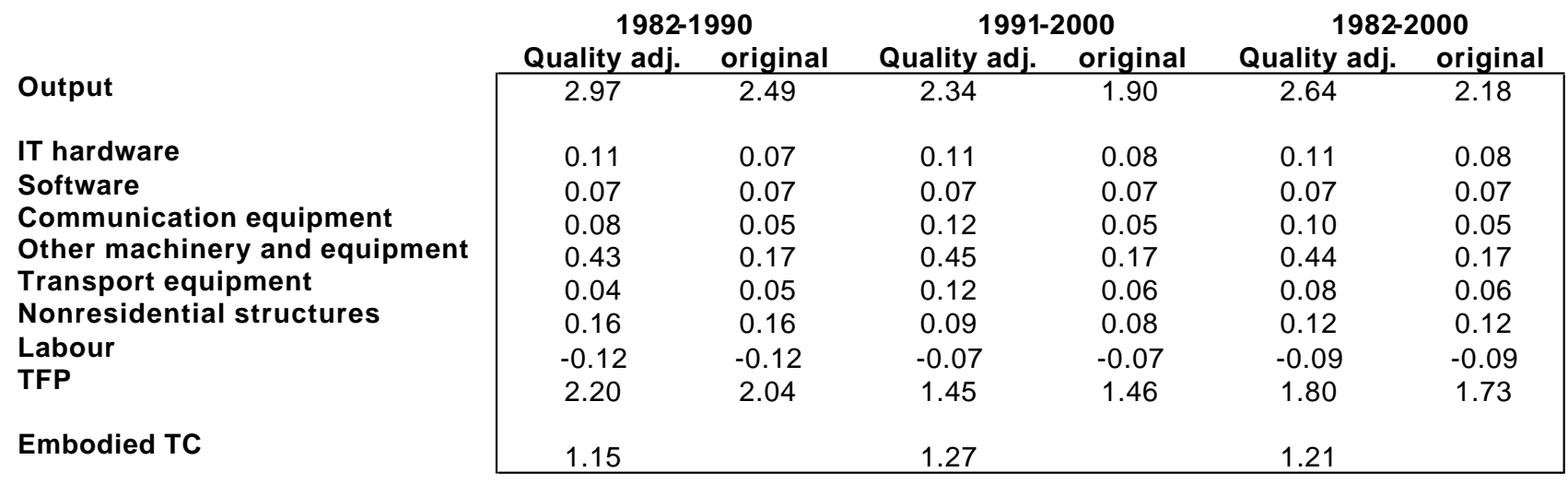

Table 6 Decomposition of output growth (percentage of total growth)

\begin{tabular}{ll|ccc|} 
& & $\mathbf{1 9 8 2 - 1 9 9 0}$ & $\mathbf{1 9 9 1 - 2 0 0 0}$ & $\mathbf{1 9 8 2 - 2 0 0 0}$ \\
\cline { 3 - 5 } Capital & & $\mathbf{0 . 3 0}$ & $\mathbf{0 . 4 1}$ & $\mathbf{0 . 3 5}$ \\
& Quality of capital & 0.19 & 0.27 & 0.23 \\
& Quantity of capital & 0.12 & 0.14 & 0.13 \\
TFP & & $\mathbf{- 0 . 0 4}$ & $\mathbf{- 0 . 0 3}$ & $\mathbf{- 0 . 0 4}$ \\
& & $\mathbf{0 . 7 4}$ & $\mathbf{0 . 6 2}$ & $\mathbf{0 . 6 8}$ \\
& Investment specific E\&S & 0.20 & 0.27 & 0.23 \\
& rest of TFP & 0.54 & 0.35 & 0.45 \\
\hline
\end{tabular}

\section{Conclusion}

Capital quality improvement is a general and widespread phenomenon that creates the necessity for proper accounting in order to avoid misleading statements about the sources of economic growth. Two adjustments need to be made in order to measure capital stock and output growth accurately. First, the prices of new capital goods need to be adjusted to reflect the improvement in quality embodied in them. Otherwise, 
output growth in the investment-good producing sector will be underestimated. Second, productive capital stocks (or more accurately, the service flows from capital that serve as input in production) should be constructed after deflating nominal investment flows by a quality-adjusted price index and depreciating old vintages with a rate that does not include quality change. Otherwise, the contribution of capital equipment to output growth is likely to be understated.

In our attempt to achieve the goal of proper accounting for euro area growth we apply the dataset of Cummins and Violante (2002) that provides quality-adjusted prices for disaggregated investment goods. Thus, we uncover substantial upward biases in the growth rates of euro area official price indexes. This has important implications for output growth itself as well as the sources of output growth. In particular, we ascribe a much more important role for capital in output growth and a correspondingly less important role for Total Factor Productivity. In itself, this reduction in the "extent of our ignorance" is very important. Furthermore, our results give rise to Embodied Technological Change as the key engine of growth in the euro area for the decades of the eighties and nineties.

We conclude with a thought that touches on the conduct of monetary policy. Clearly, it is imperative to have reliable data on inflation for that purpose. Many papers, including the present one, have stressed that there is inadequate quality adjustment of equipment price indexes. Similarly, the measured prices of consumer durables could be biased. A price bias in durable goods consumption might reduce the reliability of official inflation data making the conduct of monetary policy harder. Investigating the extent and impact of such a bias would be a fruitful avenue for future research.

\section{References}

Bahk, Byong-Hyong, and Gort, Michael. "Decomposing Learning by Doing in New Plants." Journal of Political Economy, 101(4), August 1993, pp. 561-583.

Colecchia, A. and P. Schreyer, "ICT Investment and Economic Growth in the 1990s: Is the United States a Unique Case? A Comparative Study of Nine OECD Countries", STI Working Paper 2001/7, OECD, Paris.

Cummins, Jason and Gianluca Violante, "Investment-Specific Technical Change in the United States (1947-2000): Measurement and Macroeconomic 
Consequences," Review of Economic Dynamics, v. 5(2), pp. 243-284, April 2002.

Daveri, F., "Is Growth an Information Technology Story in Europe Too?," mimeo, 2000.

Domar, Evsey, "On the Measurement of Technological Change," Economic Journal, vol. 71, pp. 709-729, 1961.

Gordon, Robert J. The Measurement of Durable Goods Prices. Chicago: University of Chicago Press, 1990.

Gordon, Robert J. "Can Technology Improvements Cause Productivity Slowdowns? Comment." In NBER Macroeconomics Annual 1996. Editors Julio J. Rotemberg and Ben S. Bernanke. Cambridge, MA: MIT Press, 1996.

Gort, Michael, and Richard Wall. "Obsolescence, Input Augmentation, and Growth Accounting.” European Economic Review, 42, 1998, pp. 1653-65.

Greenwood, Jeremy; Hercowitz, Zvi; and Krusell, Per. "Long-Run Implications of Investment-Specific Technological Change." American Economic Review, June 1997, 87(3), pp. 342-362.

Hall, Robert. "Technical Change and Capital from the Point of View of the Dual," Review of Economics Studies, 35, 1968, pp. 35-46.

Hercowitz, Zvi. "The 'embodiment' hypothesis." Journal of Monetary Economics, 41(1), February 1998, pp. 217-24.

Hobijn, Bart. "Embodiment in U.S. Manufacturing," mimeo, Federal Reserve Bank of New York, March 2001.

Hobijn, Bart, Ana Maria Oviedo and Ashwin Vasan. "Embodied Technological Change in U.S. Manufacturing," mimeo, Federal Reserve Bank of New York, December 2002.

Hornstein, Andreas, and Krusell, Per. "Can technology improvements cause productivity slowdowns?” In NBER Macroeconomics Annual 1996. Editors Julio J. Rotemberg and Ben S. Bernanke. Cambridge, MA: MIT Press, 1996.

Hulten, Charles. "Growth Accounting with Intermediate Inputs," The Review of Economics Studies, October 1978, 45 (3), pp. 511-518.

Hulten, Charles. "Growth Accounting when Technical Change is Embodied in Capital.” American Economic Review, September 1992, 82(4), pp. 964-980.

Hulten, Charles and Frank Wykoff. "The Measurement of Economic Depreciation." Depreciation, Inflation, and the Taxation of Income From Capital. Editor Charles Hulten, pp. 81-125. Washington, D.C.: Urban Institute, 1981. 
Ho, Mun and K. Stiroh, “The Embodiment Controversy: You Can't Have Two Prices in a One-Sector Model, " mimeo, 2001.

Jorgenson, Dale W., "The Embodiment Hypothesis, " Journal of Political Economy, February 1966, 74, pp. 1-17.

Jorgenson, Dale W., "Information Technology and the US Economy, " American Economic Review, 2001, 91(1), pp. 1-32.

Jorgenson, Dale W., and Griliches, Zvi. "The Explanation of Productivity Change." Review of Economic Studies, 1967, 34, pp. 249-83.

Jorgenson Dale W., Gollop F.M., Fraumeni B.M. "Productivity and US Economic Growth”, 1987, Harvard University Press, Cambridge MA

Jorgenson, Dale and Kevin Stiroh, "Raising the Speed Limit: US Economic Growth in the Information Age, ” Brookings Papers on Economic Activity, 2000, no. 2, pp. 125-211.

Licandro, Omar, JavierRuiz-Castillo, and Jorge Duran. "The Measurement of Growth under Embodied Technical Change ", EUI Working Paper 2001/14, 2001.

McGuckin, Robert and Bart van Ark, "Performance 2001, Productivity, Employment, and Income in the World's Economies, " New York: The Conference Board, 2002.

McHugh, Richard and Julia Lane, "The Age of Capital, the Age of Utilized Capital, and Tests of the Embodiment Hypothesis," The Review of Economics and Statistics, May 1987, v. 69, no. 2, pp. 362-67.

Nelson, Richard. "Aggregate Production Functions and Medium-Range Growth Projections.” American Economic Review, September 1964, 54(5), pp. 575606.

Oliner, S. D. and D. E. Sichel, "The Resurgence of Growth in the Late 1990s: Is ICT the story?" Journal of Economic Perspectives, vol. 14, no. 4, pp. 3-22, Fall.

Sakellaris, Plutarchos and Daniel Wilson, "Quantifying Embodied Technological Change," Review of Economic Dynamics, forthcoming.

Solow, Robert. "Investment and Technical Progress." In Kenneth Arrow, Samuel Karlin, and Patrick Suppes, eds., Mathematical Methods in the Social Sciences. Stanford, CA: Stanford University Press, 1960, pp. 89-104.

Vijselaar, F. and R. Albers, "New Technologies and Productivity Growth in the Euro Area," European Central Bank working paper no. 122, 2002. 
Whelan, Karl. "Computers, Obsolescence and Productivity. " Review of Economics and Statistics, 84(3), 2002, pp. 445-61.

Whelan, Karl. "A Guide to U.S. Chain Aggregated NIPA Data," Review of Income and Wealth, June 2002; 48(2): 217-33.

Wickens, Michael R, "Estimation of the Vintage Cobb-Douglas Production Function for the United States 1900-1960," The Review of Economics and Statistics, May 1970, v. 52, no.2, pp. 187-93.

You, Jon Keun, "Embodied and Disembodied Technical Progress in the United States, 1929-1968," The Review of Economics and Statistics, February 1976, v. 58, no.1, pp. 123-27. 


\section{Annex. Sectoral results}

Table A1. Quality bias (annual percentage change)

\begin{tabular}{|l|ccc|}
\hline & $1983-$ & & \\
& 1990 & $1991-2000$ & $\mathbf{1 9 8 3 - 2 0 0 0}$ \\
\hline Agriculture & 0.00 & 0.03 & 0.03 \\
foods & 0.03 & 0.02 & 0.03 \\
textiles & 0.03 & 0.02 & 0.02 \\
wood/pulp & 0.02 & 0.02 & 0.02 \\
mining & 0.03 & 0.05 & 0.04 \\
Chemicals & 0.02 & 0.03 & 0.03 \\
rubber/plastic & 0.02 & 0.02 & 0.02 \\
metals & 0.03 & 0.04 & 0.04 \\
Machinery and equipment nec & 0.03 & 0.04 & 0.03 \\
electrical and optical equipment & 0.01 & 0.02 & 0.02 \\
transport equipment & 0.02 & 0.02 & 0.02 \\
Electricity/gas/water & 0.03 & 0.03 & 0.03 \\
Construction & 0.01 & 0.01 & 0.01 \\
Wholesale and retail & 0.02 & 0.02 & 0.02 \\
hotels/restaurants & 0.02 & 0.02 & 0.02 \\
transport/storage/communication & 0.03 & 0.02 & 0.03 \\
financial intermediation & 0.03 & 0.02 & 0.02 \\
real estate, renting and business services & 0.01 & 0.01 & 0.01 \\
public administration & 0.03 & 0.03 & 0.03 \\
Education & 0.02 & 0.02 & 0.02 \\
health & 0.03 & 0.03 & 0.03 \\
other community services & 0.03 & 0.02 & 0.02 \\
\hline
\end{tabular}


Table A2. Embodied Technological change (annual percentage change)

\begin{tabular}{|l|ccc|}
\hline & $\mathbf{1 9 8 4}$ & $\mathbf{1 9 9 1 -}$ & $\mathbf{1 9 8 4}$ \\
\hline agriculture & $\mathbf{1 9 9 0}$ & $\mathbf{2 0 0 0}$ & $\mathbf{2 0 0 0}$ \\
foods & 0.03 & 0.04 & 0.04 \\
textiles & 0.02 & 0.03 & 0.03 \\
wood/pulp & 0.02 & 0.03 & 0.03 \\
mining & 0.03 & 0.03 & 0.03 \\
chemicals & 0.05 & 0.06 & 0.05 \\
rubber/plastic & 0.04 & 0.04 & 0.04 \\
metals & 0.03 & 0.03 & 0.03 \\
machinery and equipment nec & 0.07 & 0.07 & 0.06 \\
electrical and optical equipment & 0.04 & 0.05 & 0.05 \\
transport equipment & 0.03 & 0.03 & 0.03 \\
electricity/gas/water & 0.03 & 0.03 & 0.03 \\
construction & 0.03 & 0.04 & 0.03 \\
wholesale and retail & 0.03 & 0.02 & 0.02 \\
hotels/restaurants & 0.02 & 0.02 & 0.02 \\
transport/storage/communication & 0.04 & 0.04 & 0.03 \\
financial intermediation & 0.02 & 0.03 & 0.03 \\
real estate, renting and business services & 0.03 & 0.03 & 0.03 \\
public administration & 0.02 & 0.02 & 0.02 \\
education & 0.02 & 0.03 & 0.03 \\
health & 0.03 & 0.03 & 0.03 \\
Other community services & 0.03 & 0.04 & 0.03 \\
& 0.02 & 0.03 & 0.03 \\
\hline
\end{tabular}




\section{Appendix 1: Data sources and aggregation methods}

\section{Data at the aggregate level}

Value added and investment: data for value added and investment by type of asset were taken from the national accounts of France Germany, Italy and the Netherlands. These countries represent over $75 \%$ of the euro area total value added. The country data were aggregated to a euro area total estimate (for aggregation methods see below). The structural break due to German re-unification has been corrected by applying West-German growth rates to all German levels back in time, a standard approach in the economic literature. Moreover, in the case of non-ICT investment, some series had to be backcast by applying growth rates of ESA79 data to the ESA95 time series in order to construct long-enough time series. The data and detailed information on the data sources are available from the authors upon request.

Labour hours: total employment data (in persons) were taken from national accounts and average working hours from OECD (2002).

Labour share: The income share of labour $\left(\alpha_{L}\right)$ is calculated from the national accounts, by adding to total compensation of employees (which can be taken directly from the national accounts) the compensation of the self-employed, assuming that the income share of the latter category is proportional to the share of self-employed in total employment. The measure of gross value added is adjusted to exclude rental income from residential property, as residential capital is not included as a production factor in the growth accounting exercise (see below). The capital share is defined as 1 minus the labour share. In the growth accounting, variation of factor shares over time is taken into account by the use of a Törnqvist index.

Share of capital: The income share for each type of capital is calculated from the following equation:

$\alpha_{\mathrm{Kjt}}=\left(\mathrm{c}_{\mathrm{jt}} \mathrm{K}_{\mathrm{jt}}\right) /\left(\mathrm{p}_{\mathrm{yt}} \mathrm{Y}_{\mathrm{t}}\right)$

where $\mathrm{Y}$ is real gross value added, $\mathrm{K}_{\mathrm{jt}}$ is the gross current cost capital stock of the respective capital good, and $c_{\mathrm{jt}}$ the user costs of capital, which are calculated by using the following formula:

$c_{j t}=\left(r_{t}+\delta_{j t}-p_{j t}\right)$

where $\mathrm{p}_{\mathrm{jt}}$ is the expected capital gain/loss and is calculated as a three-year moving average of the annual price change of the capital good in question (following CPB 
2000 and Oliner and Sichel 2000), $\delta_{\mathrm{jt}}$ is the depreciation rate, $\mathrm{r}$ represents the nominal rate of return and is assumed to be equal over all types of stocks of capital goods.

Economic depreciation rates and average service lives are set equal to those used by the US Bureau of Economic Analysis (1999). In particular, economic depreciation rates and asset lives assumed are respectively 0.254 and 8 years for computers and related equipment, 0.15 and 11 years for telecommunications equipment, 0.1319 and 13 years for other machinery and equipment, 0.115 and 15 for transport equipment, and 0.0253 and 36 years for mn-residential construction. Investment in residential dwellings is not taken into account. The depreciation rate and service life for software, which are not determined by BEA (1999), have been set at 0.4435 and 4 years, based on assumed service lives for pre-packaged and own account software in Oliner and Sichel (2000). In particular, the net value of an intangible asset such as software can be expected to be close to zero at the end of its assumed service life. This implies a relatively large declining balance rate and thus a relatively high depreciation rate.

The rate of return is thus calculated for each year as the ex post return from the equation:

$$
\sum_{j}\left(\left(\mathrm{r}_{\mathrm{t}}+\delta_{\mathrm{jt}}-\mathrm{p}_{\mathrm{jt}}\right) \mathrm{K}_{\mathrm{jt}}\right) /\left(\mathrm{p}_{\mathrm{yt}} \mathrm{Y}_{\mathrm{t}}\right)=1-\alpha_{\mathrm{Lt}}
$$

This is the most widely used method assuming perfect foresight. It fits in with the standard equilibrium assumption used in growth accounts and has the clear advantage of being straightforward. However, as also explained in Vijselaar and Albers (2003), this measure may not reflect conditions faced by firms making investment decisions at the beginning of the period. An alternative method would be to choose an exogenous expected rate of return. This, however, would have the disadvantage of having to underpin the chosen structure of expectations. Furthermore, it would make the total value of capital services differ from the non-labour income as determined in the national accounts and thus seems a less attractive option from a consistency point of view. For a more elaborate discussion see OECD (2001).

\section{Data at the sectoral level}

The main data source used is the OECD STAN database, which contains data on a detailed (two-digit ISIC rev.3) sectoral level for gross value added, investment by sector, and employment for a number of euro area countries (Austria, Finland, France, Germany, and Italy which represent over $75 \%$ of euro area total value added). The country data were aggregated to a euro area total estimate (for aggregation methods 
see below). Employment includes self-employed persons in all cases. For investment series, data from this database are not disaggregated. Here we used a RAS-procedure to construct investment series by asset and sector. In particular, this method uses the known row (investment by $\mathrm{n}$ sectors) and column (investment by m types of asset) totals for every year, to fill out the matrix cells of a $\mathrm{n} x$ m matrix. This is done via an iterative convergence process, based on an initial distribution of the matrix cells. US ratios of investment by sector and asset were used to fill out an initial matrix to start the convergence process.

\section{Aggregation of euro area data}

Where appropriate, purchasing power parities were used to compute euro area aggregates, in accordance with standard practices for cross-country comparisons of economic growth (Van Ark 1996). 1996 EKS purchasing power weights as reported in OECD (1999) were applied. In particular, the expenditure PPPs by industry were matched to the sector distinguished for sectoral output, while investment PPPs by main type of asset were used for investment (the so-called 'proxy' PPP approach). For lack of specific PPPs for ICT capital formation, equipment PPPs were used (this choice, while far from ideal, seems the only viable solution). The use of PPPs is motivated by the need for a conversion factor which takes cross-country differences in price levels and relative price differences among expenditure categories into account. However, the alternative of applying one common conversion factor, such as the aggregate weights used by Eurostat or those used in the Area-Wide model for the euro area (Fagan et al. 2001), does not change the results significantly. The alternative of conversion at current exchange rates is not appropriate, as it does not allow for difference in price levels among countries. Moreover, current exchange rates are volatile and affected by a number of factors, such as capital movements, trade flows, and the sentiment of financial markets, which makes them unsuitable to compare fluctuations in real economic activity across countries.

\section{Aggregation of CV deflators}

The Cummins and Violante (CV) dataset contains price indexes for 25 investment goods. Since our data for the euro area are not as finely disaggregated into E\&S assets we aggregate the $\mathrm{CV}$ deflators to four asset categories: IT hardware, communication equipment, transport equipment, and other machinery and equipment. 
It seems straightforward to chain-aggregate the US data using as weights the nominal investment share of every asset in the total investment of the category to which it belongs. However, the chain-aggregated price deflators thus calculated for the four categories we distinguish would not be equal to the implicit price deflator of these categories (defined as nominal investment divided by real investment). As a result, the chain-aggregated price deflators cannot be applied to the nominal euro area E\&S investment series. The problem is that the composition within the asset categories is not known in the European case (it is for this reason that we need to chain-aggregate the US data into fewer categories in the first place).

We follow an alternative approach here where we back out implicit price deflators and apply these deflators to construct quality-adjusted real E\&S investment series for the euro area. In particular, we construct a volume index for each of our four asset categories by chain-aggregating US real investment growth from the underlying investment series using the nominal investment shares as weights. These volume series are subsequently brought to a 1995 US dollar basis. Finally, we divide the nominal investment series by the real investment series to back out the implicit price deflator for the five categories. By starting from the growth rates in real investment, rather than from the fast declining price deflators, this safeguards from overestimating real investment growth in the euro area, when applying US deflators.

Perhaps the potential problem of chain-aggregated deflators and how our alternative approach prevents this, is best explained through an example. The clearest example to consider seems to be that of information equipment. This asset category is constructed from three components in the US data: computer and peripheral equipment, photocopy and related equipment, office and accounting equipment. Obviously, we do not have the data to chain-weight, we only have the total investment in information equipment not the three components. How, then, should we calculate the euro area real series for investment in information equipment? Our approach is to construct an implicit price deflator using the US real and nominal investment series for information equipment. Chart 1 displays two alternative euro area series for real investment in information equipment. Both are based on the nominal euro area series. For one series the US deflator used is directly chain-aggregated from the CV price deflators, whereas for the other series our preferred implicit price deflator is used 
from the "backing-out" approach described earlier. The Chart shows that the direct chain-aggregated price deflators vastly overestimate euro area real investment in information equipment, especially in the second half of the 1990s.

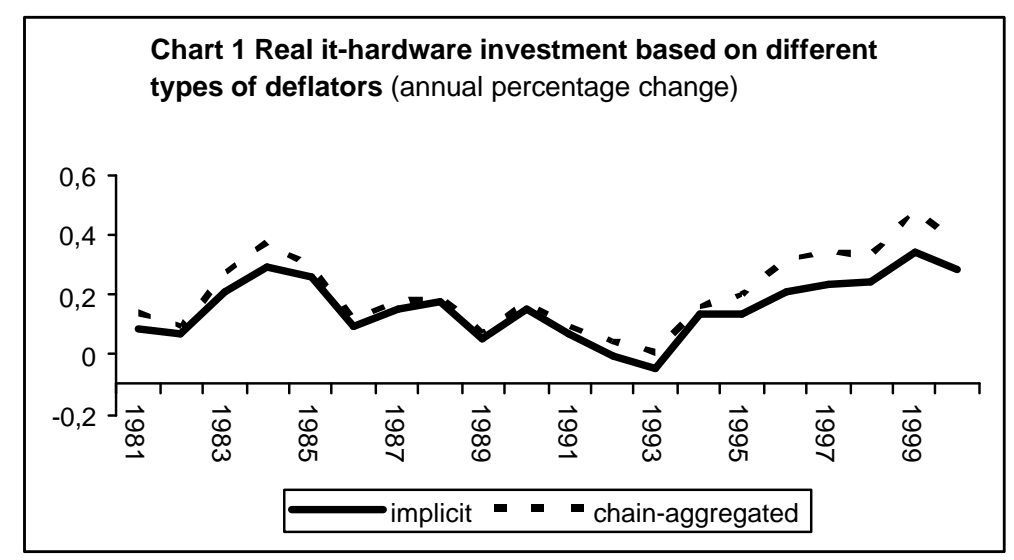

The implicit US deflators are used in a Tornquist procedure to aggregate the assetlevel price indexes into a quality-adjusted price index for E\&S in the euro area. In particular, the change in the aggregate quality-adjusted price index for E\&S is calculated using the formula:

$\Delta \log \mathrm{P}_{\mathrm{i}, \mathrm{t}}=\sum_{j} \log \left(\mathrm{P}_{\mathrm{j}, \mathrm{t}}^{\mathrm{i}} / \mathrm{P}_{\mathrm{j}, \mathrm{t}-1}^{\mathrm{i}}\right) /\left(\left(\mathrm{S}_{\mathrm{j}, \mathrm{t}}^{\mathrm{i}}+\mathrm{S}_{\mathrm{j}, \mathrm{t}-1}^{\mathrm{i}}\right) / 2\right)$

where, $S_{j}^{i}$ is the nominal investment share of type of asset $j$, and $P_{j}^{i}$ is the corresponding quality-adjusted price index. We then recover the level of the price index recursively. In doing so we allow for a different asset composition in the euro area. 


\section{European Central Bank working paper series}

For a complete list of Working Papers published by the ECB, please visit the ECB's website (http://www.ecb.int).

314 "Exchange rate risks and asset prices in a small open economy" by A. Derviz, March 2004.

315 "Option-implied asymmetries in bond market expectations around monetary policy actions of the ECB" by S. Vähämaa, March 2004.

316 “Cooperation in international banking supervision” by C. Holthausen and T. Rønde, March 2004.

317 “Fiscal policy and inflation volatility” by P. C. Rother, March 2004.

318 "Gross job flows and institutions in Europe” by R. Gómez-Salvador, J. Messina and G. Vallanti, March 2004.

319 “Risk sharing through financial markets with endogenous enforcement of trades” by T. V. Köppl, March 2004.

320 "Institutions and service employment: a panel study for OECD countries" by J. Messina, March 2004.

321 "Frequency domain principal components estimation of fractionally cointegrated processes" by C. Morana, March 2004.

322 "Modelling inflation in the euro area" by E. S. Jansen, March 2004.

323 "On the indeterminacy of New-Keynesian economics" by A. Beyer and R. E. A. Farmer, March 2004.

324 “Fundamentals and joint currency crises" by P. Hartmann, S. Straetmans and C. G. de Vries, March 2004.

325 "What are the spill-overs from fiscal shocks in Europe? An empirical analysis" by M. Giuliodori and R. Beetsma, March 2004.

326 "The great depression and the Friedman-Schwartz hypothesis" by L. Christiano, R. Motto and M. Rostagno, March 2004.

327 "Diversification in euro area stock markets: country versus industry" by G. A. Moerman, April 2004.

328 "Non-fundamental exchange rate volatility and welfare” by R. Straub and I. Tchakarov, April 2004.

329 "On the determinants of euro area FDI to the United States: the knowledge-capital-Tobin's Q framework, by R. A. De Santis, R. Anderton and A. Hijzen, April 2004.

330 "The demand for euro area currencies: past, present and future” by B. Fischer, P. Köhler and F. Seitz, April 2004.

331 "How frequently do prices change? evidence based on the micro data underlying the Belgian CPI" by L. Aucremanne and E. Dhyne, April 2004.

332 "Stylised features of price setting behaviour in Portugal: 1992-200I" by M. Dias, D. Dias and P. D. Neves, April 2004.

333 "The pricing behaviour of Italian firms: New survey evidence on price stickiness" by S. Fabiani, A. Gattulli and R. Sabbatini, April 2004. 
334 “Is inflation persistence intrinsic in industrial economies?" by A. T. Levin and J. M. Piger, April 2004.

335 “Has eura-area inflation persistence changed over time?” by G. O'Reilly and K. Whelan, April 2004.

336 "The great inflation of the 1970s" by F. Collard and H. Dellas, April 2004.

337 "The decline of activist stabilization policy: Natural rate misperceptions, learning and expectations" by A. Orphanides and J. C. Williams, April 2004.

338 "The optimal degree of discretion in monetary policy" by S. Athey, A. Atkeson and P. J. Kehoe, April 2004.

339 "Understanding the effects of government spending on consumption” by J. Galí, J. D. López-Salido and J. Vallés, April 2004.

340 "Indeterminacy with inflation-forecast-based rules in a two-bloc model” by N. Batini, P.Levine and J. Pearlman, April 2004.

34I "Benefits and spillovers of greater competition in Europe: A macroeconomic assessment" by T. Bayoumi, D. Laxton and P. Pesenti, April 2004.

342 "Equal size, equal role? Interest rate interdependence between the euro area and the United States" by M. Ehrmann and M. Fratzscher, April 2004.

343 “Monetary discretion, pricing complementarity and dynamic multiple equilibria” by R. G. King and A. L. Wolman, April 2004.

344 "Ramsey monetary policy and international relative prices" by E. Faia and T. Monacelli, April 2004.

345 “Optimal monetary and fiscal policy: A linear-quadratic approach” by P. Benigno and M. Woodford, April 2004.

346 "Perpetual youth and endogenous labour supply: a problem and a possible solution" by G. Ascari and N. Rankin, April 2004.

347 "Firms' investment decisions in response to demand and price uncertainty" by C. Fuss and P. Vermeulen, April 2004.

348 "Financial openness and growth: Short-run gain, long-run pain?” by M. Fratzscher and M. Bussiere, April 2004.

349 "Estimating the rank of the spectral density matrix" by G. Camba-Mendez and G. Kapetanios, April 2004.

350 "Exchange-rate policy and the zero bound on nominal interest rates" by G. Camba-Mendez and G. Kapetanios, April 2004.

35 I "Interest rate determination in the interbank market" by V. Gaspar, G. P. Quirós and H. R. Mendizábal, April 2004.

352 "Forecasting inflation with thick models and neural networks" by P. McNelis and P. McAdam, April 2004. 
353 "Towards the estimation of equilibrium exchange rates for CEE acceding countries: methodological issues and a panel cointegration perspective" by F. Maeso-Fernandez, C. Osbat and B. Schnatz, April 2004.

354 “Taking stock: monetary policy transmission to equity markets” by M. Ehrmann and M. Fratzscher, May 2004.

355 "Production interdependence and welfare" by K. X. D. Huang and Z. Liu, May 2004.

356 "Developing a euro area accounting matrix: issues and applications" by T. Jellema, S. Keuning, P. McAdam and R. Mink, May 2004.

357 "Seasonal adjustment and the detection of business cycle phases" by A. M. Mir and D. R. Osborn, May 2004.

358 "Did the pattern of aggregate employment growth change in the euro area in the late 1990s?" by G. Mourre, May 2004.

359 "The longer term refinancing operations of the ECB" by T. Linzert, D. Nautz and U. Bindseil, May 2004.

360 "Optimal monetary policy rules for the euro area: an analysis using the area wide model" by A. Dieppe, K. Küster and P. McAdam, May 2004.

361 "Excess reserves and the implementation of monetary policy of the ECB" by U. Bindseil, G. Camba-Mendez, A. Hirsch and B. Weller, May 2004.

362 "Oil price shocks and real GDP growth: empirical evidence for some OECD countries" by R. Jiménez-Rodríguez and M. Sánchez, May 2004.

363 "Communication and exchange rate policy" by M. Fratzscher, May 2004.

364 "Asset price booms and monetary policy" by C. Detken and F. Smets, May 2004.

365 "Exchange rates and fundamentals: new evidence from real-time data" by M. Ehrmann and M. Fratzscher, May 2004.

366 "The informational content of over-the-counter currency options" by P. Christoffersen and S. Mazzotta, June 2004.

367 "Factor substitution and factor augmenting technical: progress in the US: a normalized supply-side system approach" by R Klump, P. McAdam and A. Willman, June 2004.

368 "Capital quality improvement and the sources of growth in the euro area" by P. Sakellaris and F. W. Vijselaar, June 2004. 
